\title{
Susceptibility of Biomphalaria straminea (Dunker, 1848) from Serra da Mesa Dam, Goiás, Brazil to Infection with Three Strains of Schistosoma mansoni Sambon, 1907
}

\author{
Monica Ammon Fernandez ${ }^{+}$, Silvana Carvalho Thiengo
}

Departamento de Malacologia, Instituto Oswaldo Cruz-Fiocruz, Av. Brasil 4365, 21045-900 Rio de Janeiro, RJ, Brasil

Ecological changes from water resources development projects often affect the epidemiology of water-associated diseases. In order to investigate the occurrence and distribution of freshwater snails of medical and veterinary importance in the area of influence of the Serra da Mesa Hydroelectric a survey has been performed since 1997 and revealed the occurrence of well-established populations of Biomphalaria straminea (Dunker, 1848) in the 8 municipalities surrounding the lake. Areas of epidemiologic risk for schistosomiasis were selected and studies of parasitemollusc compatibility were undertaken using specimens from 19 populations of $\mathrm{B}$. straminea and 3 strains (CM, EC and $P B$ ) originally isolated from $\mathrm{B}$. straminea. Among 1,135 specimens used 15 became infected (infection index of $1.3 \%$ ) and 8 populations were susceptible to the schistosome strains: B. straminea from Campinorte (Castelão, susceptible to CM and EC strains, and Planeta Água, EC strain), Colinas (Tocantinzinho river, CM and EC strains), Minaçu (Canabrava river, EC strain), Niquelândia (Codemin, CM and PB strains, and Almas river, CM strain), Uruaçu (touristic area, PB strain) and Santa Rita do Novo Destino (Maranhão river, CM and EC strains). These results, associated with marked social and ecological changes occurred, strongly suggest the possibility of B. straminea coming to act as a vector of schistosomiasis in the studied area.

Key words: Biomphalaria straminea - susceptibility - Schistosoma mansoni - Serra da Mesa Dam - Goiás - Brazil

Water resources projects including man-made lakes are a matter of great concern to schistosomiasis experts for providing excellent habitats for freshwater snails and encourage close and frequent contact between people and infected water (WHO 1997). In spite of its importance to public health, studies involving parasite-mollusc compatibility in such areas are still scarce in Brazil.

The Hydroelectric of the Serra da Mesa dam (UHSM), located north in the State of Goiás (S13 $\left.49^{\prime} \mathrm{W} 48^{\circ} 18^{\prime}\right)$, is one of the most important projects related to generation of electricity in Brazil and its lake, the largest water reservoir, in terms of water volume, covers an area of 1,784 $\mathrm{km}^{2}$. Among 17 environmental programs developed in the area of influence of that dam, a survey of freshwater snails has been performed during the last 5 years, aiming to investigate the occurrence and distribution of those species of medical and veterinary importance. Considering the marked ecological and social changes that took place in that area and the presence of well-established populations of Biomphalaria straminea (Dunker, 1848) in all municipalities surrounding the lake (Barro Alto, Campinaçu,

Financial support: Furnas Centrais Elétricas SA, Serra da Mesa Energia

${ }^{+}$Corresponding author. Fax: +55-21-2280-5840. E-mail: ammon@ioc.fiocruz.br

Received 18 June 2002

Accepted 15 August 2002
Campinorte, Colinas do Sul, Minaçu, Niquelândia, Santa Rita do Novo Destino and Uruaçu), studies on parasitemollusc compatibility were undertaken.

Areas of major epidemiologic risk for schistosomiasis mansoni were selected based mainly on the results of quantitative population studies of the vector snail that have been done during the last two years. Most of 19 populations of $B$. straminea used in the experiments were obtained from those areas and two other populations $(\mathrm{Pa}-$ dre Bernardo, State of Goiás, and Picos, State of Piauí) were used as control. The snails were individually exposed to 5 Schistosoma mansoni miracidia from Camorim, State of Pernambuco (CM strain), Picos, Piauí (EC strain) and Padre Bernardo, Goiás (PB strain). The CM and EC strains were isolated as described by Fernandez and Pieri (2001). The PB strain was isolated on June 30, 1998 from feces of VP Silva, 21 years, born and grown up in Amorim, Padre Bernardo, GO, an urban focus of schistosomiasis since 1997 (Amaral \& Alves 1997), ranging approximately 300 $\mathrm{km}$ from the lake of the UHSM. The strains have been kept in sympatric snails and female Swiss albino mice. The procedures for collecting feces of infected mice and for late exposure of snails to miracidia were those described by Paraense and Corrêa (1989), and the aquaria were kept at a room temperature of $24-26^{\circ} \mathrm{C}$ throughout the experiment.

To characterize the duration of precercarial period and the infection index, the screening techniques used to detect the positive snails were those described by Paraense and Corrêa (1989). The specimens that survived for 60 days after exposure without shedding cercariae were fixed 
in Railliet-Henry's fluid, dissected and examined for developing stages of the schistosome.

Fifteen out of 1,135 exposed specimens, $2-7 \mathrm{~mm}$ in shell diameter, became infected (infection index of 1.3\%), including one with sporocysts, dissected at the end of the experiment. The results, according to the strains used, were as follows: of the 593 snails exposed to CM miracidia, 7 became infected (1.2\%); of the 379 snails exposed to EC miracidia, 6 became infected (1.6\%); and of the 163 snails exposed to PB miracidia, 2 became infected (1.2\%). As to the controls, $1.7 \%$ of 622 specimens from Picos and $12.3 \%$ of 81 from Padre Bernardo, exposed to the EC and PB S. mansoni strains, respectively, became infected.

Eight populations proved to be susceptible to the schistosome strains: the strain $\mathrm{CM}$ infected snails from Campinorte (Castelão), Colinas (Tocantinzinho river), Niquelândia (Codemin and Almas river) and Santa Rita do Novo Destino (Maranhão river); the EC strain infected snails from Campinorte (Castelão and Planeta Água), Colinas (Tocantinzinho river), Minaçu (Canabrava river) and Santa Rita do Novo Destino (Maranhão river); and the PB strain infected snails from Niquelândia (Codemin) and Uruaçu (touristic area). The duration of the precercarial period was $32 \pm 6.39$ days, varying from 25 to 44 days. For CM S. mansoni strain, the precercarial period lasted $28 \pm$ 3.41 days, varying from 25 to 34 days; for EC $S$. mansoni strain, this period lasted $37 \pm 6.87$ days, varying from 25 to 44 days; and for PB S. mansoni strain, only one mollusc emitted cercariae (30th day).

The low rates of infection in the present investigation are in accordance with those of most previous studies on experimental infection of $B$. straminea. However, infection indices up $10 \%$ were obtained by some investigators: Paraense (1967) obtained 3 positive snails of 28 specimens from Fordlândia, Pará (index of 10.7\%); Souza et al. (1983) found 11 out of 100 specimens from Jequitibá, Minas Gerais (11\%); and Fernandez and Pieri (2001) found 217 positive snails among 1,691 specimens from Camorim, Pernambuco (12.8\%). The lengthening of the precercarial period is also in accordance with that described by Favre et al. (1995) and Fernandez and Pieri (2001) for this species.

Schistosomiasis cases in the studied area were reported only to Uruaçu (Freitas 1972) and transmission sites of S. mansoni were found in Padre Bernardo, Goiânia and Distrito Federal (Crespo et al. 1965, Cunha Neto 1967).

The possibility of introduction and spread of schistosomiasis to South and Midwest regions of the country in consequence of the increasing number of new dams was emphasized by Gazin et al. (2000). The occurrence of a schistosomiasis focus at Padre Bernardo, in the same hydrographic basin, the wide range of the vector in the studied area and the intense affluence of tourists in addition to the data on susceptibility presented in this paper strongly suggest the possibility of $B$. straminea coming to act as a vector of schistosomiasis in the municipalities and point out the necessity of epidemiological vigilance.

\section{ACKNOWLEDGEMENTS}

To Furnas Centrais Elétricas SA and Serra da Mesa Energia for the facilities provided during the field work and to the $\mathrm{Bi}$ ologists Aline Carvalho de Mattos, Fernanda de Paula Araújo and Marcos Gouvêa Magalhães for technical assistance.

\section{REFERENCES}

Amaral RS, Alves MRL 1997. Foco urbano de esquistossomose no município de Padre Bernardo, GO. In XXXIII Congresso da Sociedade Brasileira de Medicina Tropical, Belo Horizonte, Abstracts p. 80.

Crespo VM, Verano OT, Barbosa JA 1965. Esquistossomose em áreas do Distrito Federal. Rev Bras Malariol D Trop 17: 357-369.

Cunha Neto AG 1967. Primeiros focos de esquistossomose mansônica em Goiânia, Estado de Goiás, Brasil. Rev Inst Med Trop São Paulo 9: 357-358.

Favre TC, Bogéa T, Rotenberg L, Silva HS, Pieri OS 1995. Cercarial emergence of Schistosoma mansoni by Biomphalaria glabrata and B. straminea. Mem Inst Oswaldo Cruz 90: 565-567.

Fernandez MA, Pieri O 2001. Infection by Schistosoma mansoni Sambon 1907 in the first four months of life of Biomphalaria straminea (Dunker, 1848) in Brazil. Mem Inst Oswaldo Cruz 96 (Suppl.): 185-192.

Freitas CA 1972. Situação atual da esquistossomose no Brasil. Rev Brasil Malariol D Trop 24: 3-63.

Gazin P, Barbosa CP, Bouvy M, Audry P 2000. Registro de ocorrência de vetores de esquistossomose mansônica em açude do Sertão de Pernambuco. Rev Soc Brasil Med Trop 33: 407-408.

Paraense WL 1967. Moluscos planorbídeos da Amazonia. Atas do Simpósio sobre a Biota Amazonica 3 (Limnologia): 187194.

Paraense WL, Corrêa LR 1989. A potential vector of Schistosoma mansoni in Uruguay. Mem Inst Oswaldo Cruz 84: 281-288.

Souza CP, Rodrigues MS, Azevedo MLL, Araujo N 1981. Suscetibilidade de populações de B. straminea (Dunker, 1848) de Minas Gerais, à infecção por Schistosoma mansoni. Rev Inst Med Trop São Paulo 23: 212-216.

WHO-World Health Organization 1997. Vector Control: Methods for Use by Individuals and Communities. Prepared by JA Rozendaal, Geneva, 412 pp. 